\title{
Demonstration of a protective immune response in infectious salmon anaemia (ISA)-infected Atlantic salmon Salmo salar
}

\author{
K. Falk ${ }^{1}$, B. H. Dannevig ${ }^{2}$ \\ ${ }^{1}$ Department of Virology, Central Veterinary Laboratory, PO Box 8156 Dep., N-0033 Oslo, Norway \\ ${ }^{2}$ Department of Morphology, Genetics and Aquatic Biology, Norwegian College of Veterinary Medicine, N-0033 Oslo, \\ Norway
}

\begin{abstract}
A protective immune response in intectious salmon anaemia (ISA)-infected Atlantic salmon Salmo salar L. was demonstrated. Atlantic salmon that had survived an ISA infection $75 \mathrm{~d}$ previously were less susceptible to reinfection. Fish passively immunized with serum from fish that had recovered from ISA were found to be partly protected against ISA. Neutralizing activity of ISAconvalescent antiserum was demonstrated by mixing convalescent antiserum with ISA-infective tissue homogenate and injecting this preparation into Atlantic salmon.
\end{abstract}

KEY WORDS: Infectious salmon anaemia Atlantic salmon - Immune response - Neutralizing antibody Passive immunity

\section{INTRODUCTION}

Infectious salmon anaemia (ISA) is a disease of farmed Atlantic salmon SaImo salar L. with a putative viral etiology (Christie et al. 1991, 1993, Thorud 1991, Dannevig \& Falk 1994). The disease is characterized by severe anaemia, leucopenia, haemorhagic liver necrosis and petechiae in several internal organs (Thorud \& Djupvik 1988, Evensen et al. 1991, Thorud 1991). Mortalities in infected populations range from 15 to $100 \%$ (Thorud 1991).

Information from commercial fish farms indicates that survivors of ISA epizootics are less susceptible to reinfection and that ISA-infected fish do not have an increased susceptibility to other viral or bacterial infections. However, information on the nature of the immune response to the ISA virus is sparse. Such information is important for understanding the pathogenesis of the disease and for isolation and identification of the ISA virus. Experimental observations suggest an immune response in ISA-infected fish. The proliferative response of head kidney leucocytes to the T-cell mitogen phytohemagglutinin (PHA) was found to have increased 1 wk post-infection (Dannevig et al. 1993). Leucocytes from the spleen of ISAinfected salmon also showed signs of macrophage activation, and increased numbers of immunoglobulin- positive cells were observed in both spleen and head kidney in the early stages of the infection (K. Falk \& C. McL. Press unpubl. data). Later in the course of infection, the head kidney leucocytes were no longer responsive to either PHA or lipopolysaccharide (LPS), indicating an impaired function of these cells (Dannevig et al. 1993). In a recent study on the infectivity of internal organs and cells from ISA-infected Atlantic salmon (Dannevig et al. 1994), it was demonstrated that leucocytes from the head kidney were important target cells for the ISA virus. Evidence has also been provided for propagation of the ISA virus in cultured salmon leucocytes (Dannevig \& Falk 1994).

The protection provided by passive transfer of serum antibodies from immune or virus-exposed fish has been used to evaluate the role of antivirus antibody in immunity to virus infections. Amend \& Smith (1974) found that serum from adult rainbow trout with antivirus activity protected young rainbow trout from infectious haematopoietic necrosis virus (IHNV). Similar results have been obtained with infectious pancreatic necrosis virus (IPNV) (Agniel 1975) and viral haemorrhagic septicaemia virus (VHSV) (de Kinkelin et al, 1977 ) in rainbow trout, with channel catfish virus (CCV) in channel catfish (Hedrick \& McDowell 1987) and with erythrocytic inclusion body syndrome (EIBS) in coho salmon (Piacentini et al. 1989) 
The presence of serum antibodies directed against virus infections in teleosts has also been investigated using in vitro neutralization tests. Rainbow trout produce neutralizing antibodies against several virus infections including IPN (Wolf \& Quimby 1969), VHS (Vestergård Jørgensen 1970) and IHN (Amend \& Smith 1974). Furthermore, Plumb (1973) detected neutralizing antibodies to CCV in channel catfish.

The purpose of the present investigation was to determine if ISA induced a protective immune response in Atlantic salmon.

\section{MATERIALS AND METHODS}

Fish and transmission trials. Transmission trials were carried out at VESO Vikan AkvaVet, Namsos, Norway. Adult Atlantic salmon (average size $2.5 \mathrm{~kg}$ ) that had survived an ISA outbreak 1 yr earlier were obtained from a commercial fish farm and transported to Vikan AkvaVet. The fish were kept in a tank supplied with sea water (salinity $32 \%$ ) at a water temperature of 8 to $10^{\circ} \mathrm{C}$. Presmolts (25 to $40 \mathrm{~g}$ ) and smolts (50 to $60 \mathrm{~g}$ ) were obtained from a local freshwater salmon hatchery where ISA has never been diagnosed. Presmolts were kept in fresh water and smolts in fresh water supplied with sea water to give a final salinity of $15 \%$ at a water temperature of $12^{\circ} \mathrm{C}$. The fish were fed once a day with standard salmon pelleted food

Infective material was injected intraperitoneally in anaesthetized $10.005 \%$ ethyl-4-aminobenzoate, benzocaine; BDH Chemicals, Poole, UK) fish. Mortalitjes were recorded daily and ISA infection was verified by post mortem examination according to specified diagnostic criteria including presence of ascites, congestion of liver and spleen, pallor of the gills and petechiae in the visceral fat (Dannevig et al. 1993).

Preparation of ISA-infective tissue homogenate. Tissue homogenate was prepared as described by Dannevig et al. (1993). Briefly, liver, kidney and spleen tissues from moribund Atlantic salmon suffering from ISA were mixed and homogenized $(10 \%, w / v)$ in Earle's balanced salt solution, pH 7.4 (EBSS), supplemented with antibiotics (penicillin, $100 \mathrm{U} \mathrm{ml}^{-1}$; streptomycin, $100 \mu \mathrm{g} \mathrm{ml}^{-1}$; kanamycin, $200 \mathrm{\mu g} \mathrm{ml}^{-1}$; final concentration), centrifuged at $13000 \times g$ for $45 \mathrm{~min}$ and passed through a $220 \mathrm{~nm}$ membrane filter. The homogenate was divided into aliquots and stored at $-70^{\circ} \mathrm{C}$ until used.

Convalescent antiserum. Forty-two adult salmon that had survived an ISA outbreak were exposed to the ISA virus by cohabitation with 100 smolts that had received an injection of $0.5 \mathrm{ml}$ of ISA-infective tissue homogenate. After 13 wk, blood was collected from the fish by puncturing the caudal vein. The blood samples were kept at $4^{\circ} \mathrm{C}$ overnight before separation of serum and cells. Convalescent antisera from 8 fish were pooled. Sera from 5 fish were obtained from a farm where ISA has never been diagnosed, pooled, and used as a nonimmune control serum. The sera were heat-inactivated for $30 \mathrm{~min}$ at $45^{\circ} \mathrm{C}$ and stored at $-40^{\circ} \mathrm{C}$ until used.

Purification of salmon immunoglobulin. Serum immunoglobulin was purified by gel filtration (Superose 6. HR 16/50; Pharmacia, Uppsala, Sweden) followed by anion exchange chromatography (Mono Q. HR 5/5; Pharmacia) according to Håvarstein et al. (1988). The protein concentration of the purified immunoglobulin fraction was adjusted to $1 \mathrm{mg} \mathrm{ml}^{-1}$ and the preparations were stored at $-40^{\circ} \mathrm{C}$

Resistance to reinfection. Twenty smolts that had survived an artificially induced ISA infection $75 \mathrm{~d}$ earlier received a further injection of $0.5 \mathrm{mI}$ of ISAinfective tissue homogenate (final tissue concentration $1 / 1000 \mathrm{w} / \mathrm{v}$ in EBSS). Forty smolts that had never been exposed to the ISA virus received an injection of the same material. Both groups were kept in the same tank.

Passive immunization. Forty presmolts each received an intraperitoneal injection of $0.1 \mathrm{ml}$ undiluted convalescent antiserum $2 \mathrm{~d}$ before injection of $0.25 \mathrm{ml}$ ISA-infective tissue homogenate (final tissue concentration $1 / 100 \mathrm{w} / \mathrm{v}$ in EBSS). Another group of 40 presmolts received nonimmune control serum before injection of ISA-infective tissue homogenate. Both groups were kept in the same tank.

Detection of neutralizing activity. Undiluted convalescent antiserum, nonimmune control serum and purified immunoglobulin fractions from the same sera were mixed with equal volumes of ISA-infective tissue homogenate diluted in EBSS. Final concentration (w/v) of ISA-infective tissue homogenate was $1 / 100$ for the experiments with serum and 1/500 for the experiment with purified immunoglobulin fractions. All preparations were kept on ice overnight prior to inoculation of presmolts ( $n=40$ for each group)

Statistical analysis. Cox proportional hazards survival analysis was used to compare mortality between groups in the experiments. Hazard ratios (HR) with $95 \%$ confidence intervals and the corresponding $\mathrm{p}$ values were calculated using the statistical package EGRET (Statistics and Epidemiology Research Corporation, Seattle, WA, USA).

\section{RESULTS}

Of 42 adult salmon which had survived an ISA outbreak 1 yr earlier, 18 died of ISA after cohabitation with ISA-inoculated smolts. Convalescent antiserum 


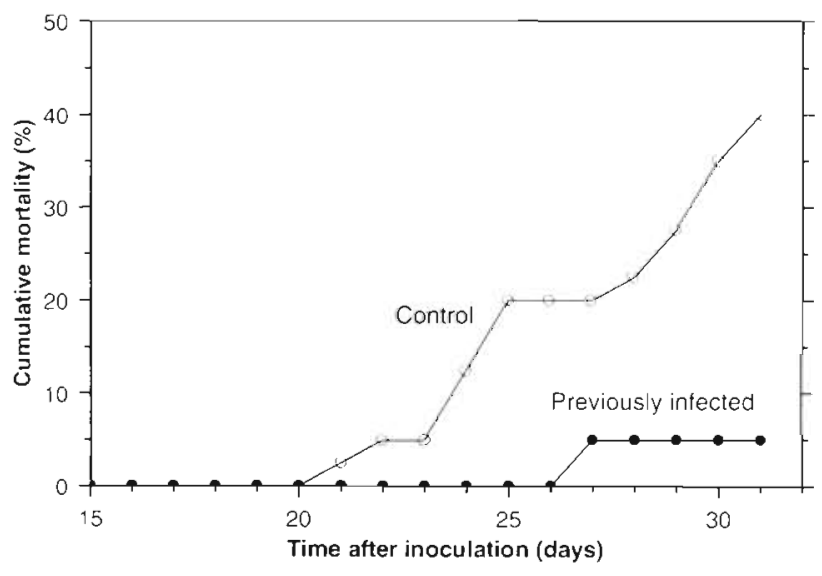

Fig. 1. Salmo salar. Resistance to ISA reinfection. Cumulative mortalities $(\%)$ among Atlantic salmon presmolts that had survived an artificially induced ISA infection $(\bullet, \mathrm{n}=20)$ and among control salmon presmolts $(\mathrm{O}, \mathrm{n}=40)$ after intraperitoneal injection with an ISA-infective tissue homogenate

from surviving fish was collected and used in the subsequent experiments.

In the present study, mortality of injected fish commenced between 13 and $21 \mathrm{~d}$ post injection (see Figs. 1 to 3 ). The post mortem examinations of these fish were consistent with ISA.

\section{Resistance to reinfection}

Following injections of infective material, the mortality of fish that had previously recovered from ISA infection (Fig 1) was significantly lower than for the con-

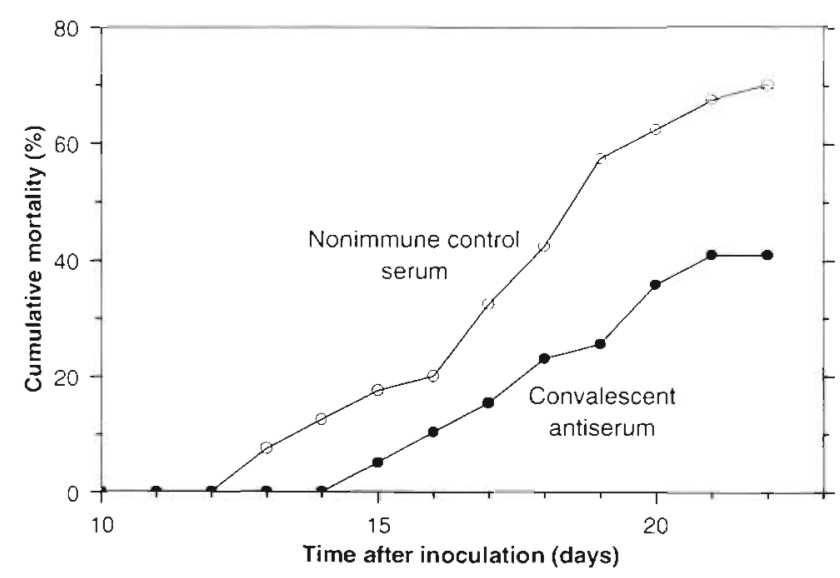

Fig. 2. Salmo salar. Passive immunization against ISA. Cumulative mortalities (\%) among Atlantic salmon presmolts intraperitoneally injected with an ISA-infective tissue homogenate after passive immunization with convalescent antiserum from ISA-infected salmon $(\bullet, n=40)$ or after injection with nonimmune control serum $(0, n=40)$ trol fish ( $\mathrm{HR}=0.1045 ; \mathrm{p}=0.028)$. Only 1 of the fish that had previously recovered from ISA infection $(n=20)$ died during the course of this study, while 16 of 40 control fish died.

\section{Passive immunization}

Fish that received ISA-convalescent antiserum were found to be partly protected against ISA-induced mortality. A significantly lower mortality $(\mathrm{HR}=0.4381 ; \mathrm{p}=$ 0.009 ) was observed for fish that received convalescent antiserum intraperitoneally $2 \mathrm{~d}$ before injection of ISA-infective material, compared to fish that received control serum (Fig. 2). During the course of this study, 16 of 40 fish receiving convalescent antiserum died. In contrast, 28 of 40 fish receiving normal serum died.

\section{Detection of neutralizing activity}

A significant reduction in mortality $(\mathrm{HR}=0.2063 ; \mathrm{p}<$ 0.001 ) was demonstrated when the ISA-infective tissue homogenate was mixed with crude convalescent antiserum before injection into experimental fish (Fig. 3a). In another experiment, purified immunoglobulin fractions from convalescent antiserum and nonimmune control serum, respectively, were mixed with ISAinfective material before injection into experimental fish (Fig. 3b). A significant reduction in mortality was observed in fish injected with the immunoglobulin fraction from convalescent antiserum compared to the control group $(\mathrm{HR}=0.2345 ; \mathrm{p}=0.026)$.

\section{DISCUSSION}

The present results show that Atlantic salmon which had survived an outbreak of ISA infection $75 \mathrm{~d}$ earlier were less susceptible to reinfection. This finding agrees with field observations that survivors of ISA epizootics are less susceptible to reinfection.

Both the humoral and cell-mediated immune systems respond to virus infections. The role of specific humoral antibody is mainly to provide resistance to reinfection by limiting the dissemination of virus (Mims \& White 1984). Passive immunization can be used to evaluate the relative contributions of cellular immunity and serum antibodies to protection against disease. In this study, fish that received ISA-convalescent antiserum were protected against ISA, suggesting that humoral factors are important in a successful immune response to ISA.

Passive immunization of rainbow trout against VHSV (de Kinkelin et al. 1977) and IHNV (Amend \& 

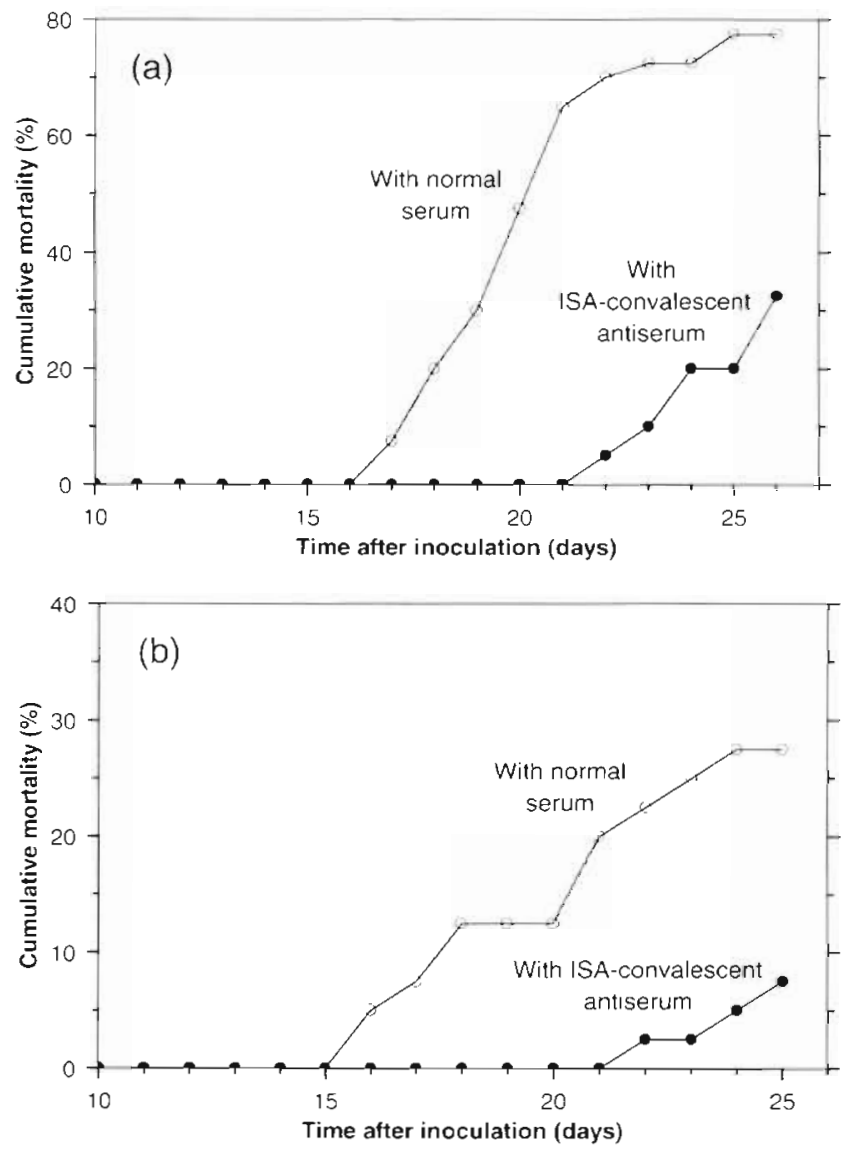

Fig. 3. Salmo salar. Neutralization of the ISA virus with ISAconvalescent antiserum. ISA-infective tissue homogenate was mixed with ISA-convalescent antiserum $(\bullet, n=40)$ or with normal serum $(0, n=40)$ and intraperitoneally injected into Atlantic salmon presmolts. (a) Crude serum; (b) purified immunoglobulin fraction

Smith 1974) and of channel catfish against CCV (Hedrick \& McDowell 1987) showed a higher degree of protection than was observed in this study for passive immunization against ISA. However, the various studies are not necessarily comparable, due to the different procedures and different infectious agents used. The route of infection, the dose of infectious agent and the titre of antiserum will all influence the outcome of passive immunization. Indeed, the experiments that examined neutralizing activity (discussed below) suggest that the neutralizing titre of the convalescent antiserum used in the present study was low.

Since the ISA virus has not yet been successfully propagated, traditional in vitro neutralization tests for the demonstration of specific antibodies could not be used. Therefore, neutralizing activity was investigated by mixing heat-inactivated convalescent antiserum with an ISA-infective tissue homogenate before injection into fish. A significant neutralizing effect of the
ISA-convalescent antiserum was observed. The final dilution of antiserum was 2-fold. Only a partial neutralization was obtained in this experiment and it appeared that the neutralizing activity of the convalescent serum was low. However, a relatively high challenge dose of infective material was used. A lower dose of infective material might have produced a higher, more marked neutralizing activity. The neutralizing activity of the convalescent antiserum may also have been due to nonspecific factors. However, the serum was inactivated to avoid the influence of complement factors. Furthermore, control fish were injected with a control preparation using a pool of serum from non-ISA-exposed fish and there was no evidence of neutralizing activity in the nonimmune control serum. To verify that the observed serum neutralization of ISA infectivity could be ascribed to antibodies, the immunoglobulin fraction of the convalescent antiserum was isolated and tested for neutralizing activity. Although the mortality in the control group was low in this experiment, a clear effect of the immunoglobulin fraction from ISA-convalescent antiserum could be seen. Thus, a major part of the ISA-neutralizing activity of salmon serum appeared to be associated with the immunoglobulin fraction.

Although the present study has demonstrated a protective immune response in Atlantic salmon against the ISA virus, the response does not appear to provide full protection against the disease. High mortality is usually observed in both naturally and experimentally infected fish (Thorud 1991, Dannevig et al. 1993). Replication of the ISA virus in leucocytic cells, which has been demonstrated both in vivo and in vitro (Dannevig \& Falk 1994, Dannevig et al. 1994), may interfere with the immune mechanisms involved in defence against the virus. This assumption is supported by experimental data indicating impaired leucocyte functions in the terminal stages of an ISA infection (Dannevig et al. 1993). Hence, the relatively low neutralizing activity observed in convalescent antiserum in the present study could be the result of an impaired immune response caused by virus infection of immune cell populations. However, observations from ISA-diagnostic work indicate that ISA-infected fish are not more susceptible to other viral or bacterial infections. The discrepancy between experimental and field observations emphasizes the need for further investigation of the nature of the immune response to ISA.

Acknowledgements. We thank Inger Austrheim and Grete Berntsen at the laboratory and Sigmund Sevatdal at Vikan AkvaVet for their excellent technical assistance. This study was financially supported by the Agricultural Research Council of Norway and the Norwegian Fishenes Research Council. 


\section{LITERATURE CITED}

Agniel LD (1975) An assessment of passive transfer of immunity to infectious pancreatic necrosis virus (IPNV) in trout. MSC thesis, American University, Washington, DC

Amend DF, Smith L (1974) Pathophysiology of infectious hematopoietic necrosis virus disease in rainbow trout Salmo gairdners: early changes in blood and aspects of the immune response after injection of IHN virus. J Fish Res Bd Can 31:1371-1378

Christie KE, Hjeltnes B, Lorens JB, Namork E, Nerland AH (1991) A search for specific gene sequences from the etiological agent of infectious salmon anemia. In: 2nd int. Symp. on Viruses of Lower Vertebrates, 20-31 July 1991 Oregon State University Press, Corvallis, $p$ $117-124$

Christie KE, Hjeltnes B, Uglenes I, Winton JR (1993) Determination of buoyant density and sensitivity to chloroform and freon for the etiological agent of infectious salmon anaemia. Dis aquat Org 15:225-228

Dannevig BH, Falk K (1994) Atlantic salmon, Salmo salar L., develop infectious salmon anaemia (ISA) after inoculation with in vitro infected leucocytes. J Fish Dis 17:183-187

Dannevig BH, Falk K, Krogsrud J (1993) Leucocytes from Atlantic salmon, Salmo salar L., experimentally infected with infectious salmon anaemia (ISA) exhibit an impaired response to mitogens. J Fish Dis 16:351-359

Dannevig BH, Falk K, Skjerve E (1994) Infectivity of internal organs and cells of Atlantic salmon (Salmo salar L.) experimentally infected with the aetiological agent of infectious salmon anaemia (ISA). J Fish Dis 17:613-622

de Kinkelin P, Gerard JP, Dorson M, Le Berre M (1977) Viral hemorrhagic septicemia: demonstration of a protective

Responsible Subject Editor: F. M. Hetrick, College Park, Maryland, USA immune response following natural infection. Fish Health News 6:3-4

Evensen O, Thorud KE, Olsen YA (1991) A morphological study of the gross and light microscopic lesions of infectious anaemia in Atlantic salmon (Salmo salar). Res Vet Sci $51: 215-222$

Håvarstein LS, Aasjord PM, Ness S, Endresen C (1988) Purification and partial characterization of an IgM-like serum immunoglobulin from Atlantic salmon (Salmo salar). Dev comp Immunol 12:773-785

Hedrick RP, McDowell T (1987) Passıve transfer of sera with antivirus neutralizing activity from adult channel catfish protects juveniles from channel catfish virus disease. Trans Am Fish Soc 116:277-281

Mims CA, White DO (1984) Viral pathogenesis and immunology. Blackwell Scientific Publications, London

Piacentini SC, Rohovec JS, Fryer JL (1989) Epizootiology of erythrocytic inclusion body syndrome. $J$ aquat Anim Health 1:173-179

Plumb JA. (1973) Neutralization of channel catfish virus by serum of channel catfish. J Wildl Dis 9:324-330

Thorud K (1991) Infectious salmon anaemia. PhD thesis, Norwegian College of Veterinary Medicine, Oslo

Thorud KE, Djupvik HO (1988) Infectious anaemia in Atlantic salmon (Salmo salar L.). Bull Eur Ass Fish Pathol 8: $109-111$

Vestergård-Jørgensen PE (1970) Egtved virus: demonstration of neutralizing antibodies in serum from artificially infected rainbow trout (Salmo gairdneri). J Fish Res. Bd Can 28:875-877

Wolf K, Quimby MC (1969) Infectious pancreatic necrosis: clinical and immune response of adult trouts to inoculation with live virus. J Fish Res Bd Can 26:2511-2516

Manuscript first received: April 26, 1994

Revised version accepted: June 28, 1994 